This item was submitted to Loughborough's Research Repository by the author.

Items in Figshare are protected by copyright, with all rights reserved, unless otherwise indicated.

\title{
Allocation of scarce water resources using deficit irrigation in rotational systems
}

PLEASE CITE THE PUBLISHED VERSION

PUBLISHER

(C) American Society of Civil Engineers (ASCE)

LICENCE

CC BY-NC-ND 4.0

REPOSITORY RECORD

Gorantiwar, S.D., and lan K. Smout. 2019. "Allocation of Scarce Water Resources Using Deficit Irrigation in Rotational Systems". figshare. https://hdl.handle.net/2134/3607. 
This item was submitted to Loughborough's Institutional Repository by the author and is made available under the following Creative Commons Licence conditions.

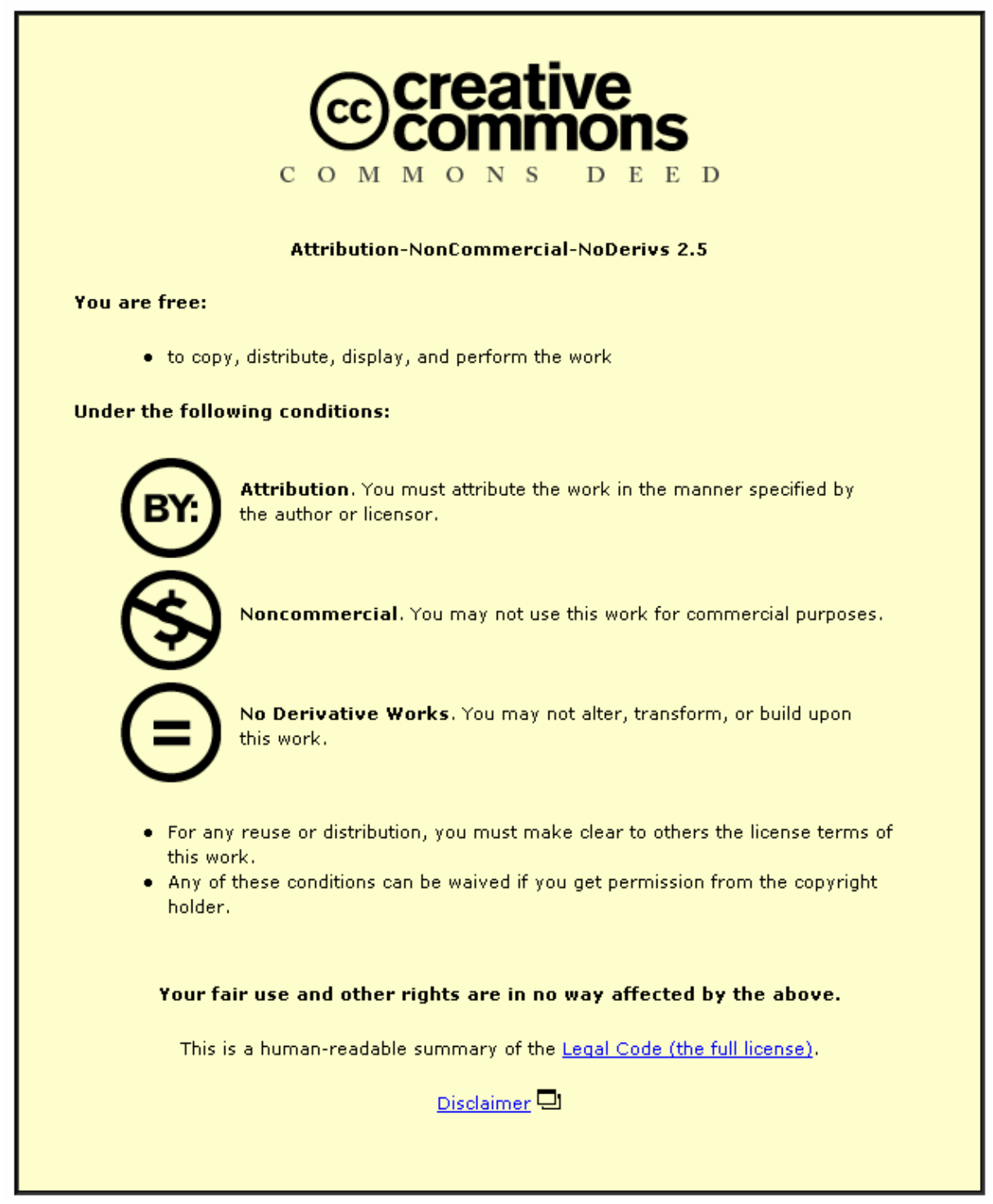

For the full text of this licence, please go to: http://creativecommons.org/licenses/by-nc-nd/2.5/ 


\title{
ALLOCATION OF SCARCE WATER RESOURCES USING DEFICIT IRRIGATION IN ROTATIONAL SYSTEMS
}

\section{S.D.Gorantiwar ${ }^{1}$ and I.K.Smout ${ }^{2}$}

\begin{abstract}
On irrigation schemes with rotational irrigation systems in semiarid tropics, the existing rules for water allocation are based on applying a fixed depth of water with every irrigation irrespective of the crops, their growth stages and soils on which these crops are grown. However when water resources are scarce, it is necessary to allocate water optimally to different crops grown in the irrigation scheme taking account of different soils in the command area. Allocating water optimally may lead to applying less water to crops than is needed to obtain the maximum yield. In this paper, a three stage approach is proposed for allocating water from a reservoir optimally based on a deficit irrigation approach, using a simulation-optimization model. The allocation results with a deficit irrigation approach are compared for a single crop (wheat) in an irrigation scheme in India, firstly with full irrigation (irrigation to fill the root zone to field capacity) and secondly with the existing rule. The full irrigation with a small irrigation interval was equivalent to adequate irrigation (no stress to the crop). It is found that practising deficit irrigation enables the irrigated area and the total crop production in the irrigation scheme used for the case study to be increased by about 30$45 \%$ and $20-40 \%$, respectively over the existing rule and by $50 \%$ and $45 \%$, respectively over the adequate irrigation. Allocation of resources also varied with soil types.
\end{abstract}

\footnotetext{
${ }^{1}$ Academic Visitor, Water, Engineering and Development Centre, Loughborough University, Loughborough, Leics., LE11 3TU, UK

2 Director, Water, Engineering and Development Centre, Loughborough University, Loughborough, Leics., LE11 3TU, UK
} 
Keywords. Soil water balance, Adequate irrigation, Deficit irrigation, Optimum land and water allocation

\section{INTRODUCTION}

In irrigation schemes under a rotational water supply in the semi-arid tropics, normally the fixed depth of water is applied with every irrigation, scheduled at a fixed interval (existing rule), for ease of operation of the irrigation schemes. However with limited water available for irrigation in those schemes, as indicated by an average irrigation intensity of 30 to $40 \%$ (Shanan, 1992), it is now obvious that irrigation water needs to be allocated optimally by considering varied crops, their growth stages, different soils existing in the irrigation schemes and efficiencies at different stages of movement of water from the reservoir to the root zone.

Numerous techniques have been developed for optimal allocation of water resources, based on optimization models. These techniques broadly fall into two categories. In the first category, the water is allocated to different crops according to their water requirement for producing maximum yield per unit area, and hence the area to be irrigated under different crops is pre-determined (Afshar and Marino, 1989; Mayya and Prasad, 1989; Paudyal and Gupta, 1990; Thandaveswara, 1992; Shyam et al., 1994 and Onta et al., 1995). However in water limiting conditions, allocating less water than the maximum water requirement may produce more production than allocating water equivalent to the maximum water requirement.

In the second category, the water allocation considers several alternative levels of water applied (and in some cases, alternative intraseasonal distributions) and the corresponding yield over the entire season, either by specifying the area to be irrigated by 
each crop (Dudley et al., 1971; Schmidt and Plate, 1980; Bras and Cordova, 1981; Rhenals and Bras, 1981; Loftis and Houghtalen, 1987; Rao et al., 1990; Vedula and Mujumdar, 1992; Akhand et al., 1995; Wardlaw and Barnes, 1999 and Paul et al., 2000) or by deciding the optimal areas to be irrigated under different crops (Matanga and Marino, 1979; Sudar et al., 1981; Yaron and Dinar, 1982; Rao et al., 1986; Sritharan et al., 1988; Bernardo et al., 1988; Martin et al., 1989; Shyam et al., 1994 and Onta et al., 1995). The different combinations of water applied and yield which are considered in these studies are mostly based on developing a seasonal water production function for each crop. In these cases, allocation is based on the optimum intraseasonal distribution of seasonal depth of water by a dynamic programming approach and hence by considering the deficit irrigation. However in the further optimization process (either optimum allocation of water or both area and water), the deficit itself is not distributed optimally over both different intraseasonal periods and area.

At a scheme level, the problem also needs to be solved differently due to variation in soil types, different irrigation efficiencies at different application levels, and sensitivity of crops to water application during different crop growth stages. The most appropriate approach in a multicrop and water limiting situation is to use several sets of water application depths based on combination of full and deficit irrigation over different irrigation or intraseasonal periods, and the corresponding crop yields. This approach is adopted in this paper to include deficit irrigation in the optimization process. The set of irrigation depths per irrigation application and crop yield or net benefits per unit area is termed an 'irrigation program' in this paper.

In the present paper, several irrigation programs are generated for each crop-soil combination, by using a soil water balance crop growth simulation model and including deficit irrigation and irrigation efficiencies at different stages. Deficit irrigation is included by considering irrigation depths to bring the soil to field capacity i.e. full irrigation and to 
below field capacity i.e. partial irrigation. These programs are then incorporated in a resource optimization model to allocate land and water optimally for irrigation schemes, where shortages of water prevent adequate irrigation of the whole irrigable command area of the irrigation scheme. The allocation of land and water resources obtained with deficit irrigation using the model developed in this study is compared with the existing rule of applying a fixed depth of irrigation water and with full irrigation, by using a case study for a single crop (wheat) grown on an irrigation scheme in a semi-arid region in western India. This demonstrates the influence of soil type and irrigation interval on allocation of the resources by existing and proposed rules. In these irrigation systems, the irrigation interval is assumed to be pre-determined and uniform for all crop and soil combinations.

The terms full irrigation and partial irrigation in the context of deficit irrigation are described in the next section.

\section{DEFICIT IRRIGATION}

Deficit irrigation has been defined as deliberate underirrigation of a crop (English and Nuss, 1982 and English, 1990), purposefully planned underirrigation (Keller et al., 1992) or deliberate stressing of crops (Hargreaves and Samani, 1984) to influence the yield or profit. Trimmer (1990) defined deficit irrigation similarly as the practice of scientifically underirrigating crops to reduce yield in a controlled way. The purpose of the underirrigation was to spread available water over a large area, thereby increasing the total production from the irrigation scheme or reducing the total use of water or energy per unit area irrigated. All these researchers explained the effect of deficit irrigation in reducing the seasonal depth of irrigation. The present paper is concerned with optimizing the depth of irrigation per application in a water limiting condition and a multicrop and soil situation to obtain the 
maximum output (in the form of crop production or net benefits) from the irrigation scheme, so the terminology is elaborated further.

The inadequacy of available water supplies to irrigate the entire arable land presents two alternatives to the irrigator:

(1) Irrigate a limited area by applying water equivalent to the maximum crop water requirement so that the crop is not subjected to water stress, and maximum yields per hectare of irrigated area are obtained. This is called "adequate irrigation".

(2) Irrigate more land than can be irrigated with option (1) by applying less water than the maximum crop water requirement, causing stress to the crop and resulting in reduced yield per hectare but with more land under irrigation. This is called "deficit irrigation".

Adequate irrigation gives the maximum crop yield per unit of land irrigated. Deficit irrigation could be followed to give the maximum crop yield per unit of water utilized and/or maximum total production (and/or maximum net benefits) over the irrigation scheme. The practices of adequate and deficit irrigation can be followed by applying full or partial irrigation at each irrigation depending on the interval between two irrigations. For a small irrigation interval, even with partial irrigation, stress may not occur, and for a large irrigation interval, stress may also be caused with full irrigation. Thus the adequate irrigation is: applying full or partial irrigation at each irrigation with the interval between irrigations adjusted to maintain maximum crop evapotranspiration (ET) and thus not to cause any stress, so that maximum crop yields are obtained. Deficit irrigation is: applying full or partial irrigation at each irrigation but with the interval between them causing actual crop ET to drop below maximum crop ET, which results in stress and subsequent reduction in crop yield and in the process using less water than for adequate irrigation.

With finite supplies of water, many researchers found that applying less water than required for maximum yield, is beneficial in terms of profit (English and Nuss,1982; Reddy 
and Clyma,1983; Hargreaves and Samani,1984; English,1990; Trimmer,1990 and Keller et al., 1992). In deficit irrigation, the crop is subjected to water stress resulting in a reduction of crop yield which depends on the timing and amount of deficit. The deficit can be obtained by following three approaches.

Approach-1 : Prolonging the interval between two irrigation applications beyond the irrigation interval which would not cause any stress to the crop, if the root zone was filled up to field capacity, and applying water to bring soil moisture in the root zone to field capacity. The crop is subjected to stress at the end of each irrigation period (the case of full irrigation with a large irrigation interval).

Approach-2 : Applying less water than the amount required to bring the soil moisture in the root zone to field capacity, with an irrigation interval which would not cause any stress if the root zone was filled up to field capacity (the case of partial irrigation with a small irrigation interval).

Approach-3 : Combination of (1) and (2) i.e. by prolonging the irrigation interval beyond the one which does not cause any stress when the root zone is filled to its field capacity and applying less water than required to bring the soil root zone to field capacity (the case of partial irrigation with a large irrigation interval).

Fig. 1 shows the soil water status in the root zone in response to irrigation compared to soil water at field capacity and wilting point and readily available soil water and illustrates all these approaches schematically. The readily available soil moisture is obtained from allowable depletion which is a function of maximum crop evapotranspiration (Doorenbos and Kassam, 1986). In the present study full and partial irrigations are applied for different irrigation intervals and therefore Approach-2 is practised for smaller irrigation intervals and 
Approach-1 and Approach-3 are practised for large irrigation intervals. However as the allocation model is developed for irrigation schemes with large command areas and rotational irrigation systems, the irrigation interval is kept the same for all crops in the season and all soils in the command. Application of less water is indicated by a term 'deficit ratio' which is prescribed for each irrigation application and is the ratio of the amount of water applied to the root zone to the amount of water required to fill the root zone to field capacity. Each combination of crop and soil is referred to as a 'unit'.

\section{RESOURCE ALLOCATION MODEL WITH DEFICIT IRRIGATION}

A three stage resource allocation model with deficit irrigation, Area and Water Allocation Model (AWAM), which uses a simulation optimization technique was developed. The three stages are

(1) Generation of alternative irrigation programs based on deficit irrigation for each unit

(2) Selection of optimal irrigation programs

(3) Allocation of the resources (land and water)

The model is described in detail by Gorantiwar (1995). In this paper the important features of the model are presented. The flow chart of model, AWAM, is presented in Fig. 2.

\section{Stage 1: Generation of Alternative Irrigation Programs}

In the present study, the term "irrigation strategy" is used to represent, for a particular irrigation interval, the values of deficit ratios associated with each irrigation application. There can be several irrigation strategies and these are obtained by different combinations of deficit ratio for each irrigation application. In this stage the irrigation programs are generated for different irrigation strategies for the unit by formulating Soil WAter Balance - Crop Yield 
Benefit (SWAB-CRYB) simulation model. This model has some default procedures or models for simulation of many parameters (Retta and Hanks, 1980; Doorenbos and Pruitt, 1984; Doorenbos and Kassam, 1986; Walker and Skogerboe, 1987; Bos and Nugteren, 1990 and Smith, 1991) but also allows the user to stipulate other procedures or models or make direct input of certain parameters. The model SWAB-CRYB is formulated to make it applicable to major field crops grown in the command area of an irrigation scheme. It uses the data which are generally available at the irrigation scheme, if any, and general data documented by FAO (Doorenbos and Pruitt, 1984 and Doorenbos and Kassam, 1986), if local data are not available. The soil water balance part of this model represents the system more descriptively than used in most allocation studies. The model SWAB-CRYB involves various inflow and outflow processes, a soil water balance equation and crop growth model. The details of the SWAB-CRYB model are described by Gorantiwar (1995).

\section{Stage 2: Selection of Optimal Irrigation Programs}

At this stage optimal irrigation programs are selected from all the irrigation programs generated at stage-1 for each irrigation strategy. A strategy consists of a series of irrigations, each of which may have a different deficit ratio.

Total irrigation programs : If ' $\Delta \mathrm{a}$ ' is the increment chosen between deficit ratios, the number of possible deficit ratios (na) is computed by equation (1).

$$
\text { na }=\{(\operatorname{amax}-\operatorname{amin}) / \Delta \mathrm{a}\}+1
$$

where amax = maximum value of deficit ratio (usually one) and amin $=$ minimum value of deficit ratio (usually zero). The total number of irrigation strategies considered (P) is computed by equation (2). 


$$
\begin{array}{ll}
\mathrm{P}=\mathrm{na}^{(\mathrm{Ic}-1)} & \text { if first irrigation is to fill entire root zone } \\
\mathrm{P}=\mathrm{na}^{\text {Ic }} & \text { otherwise }
\end{array}
$$

where Ic $=$ total number of irrigation applications (excluding presowing irrigation). The presowing irrigation, if needed, is given to fill the soil zone to field capacity. Thus there can be ' $\mathrm{P}$ ' total irrigation programs (corresponding to $\mathrm{P}$ irrigation strategies). The optimal irrigation programs (OIPs) are selected from these total irrigation programs. The OIP is the irrigation program with an output more than the output from other irrigation programs but with a seasonal irrigation depth the same or less than the seasonal irrigation depth of other irrigation programs. It is obvious that in a water limiting condition and multicrop and soil situation, one or more OIP(s) can appear in the solution. If the number of irrigation programs to be transferred to the third stage is to be limited due to the restriction on the number of variables that can be considered in the optimization model of stage-3, only those OIPs are selected which give a higher marginal increase in yield (net benefits) with increase in water applied than the other OIPs. These programs are referred to as selected OIPs (SOIPs). In other words these are the most economically efficient optimal irrigation programs. There may be a small possibility of losing optimality by restricting the number of OIPs but it can be risked for computational feasibility. This has been confirmed by comparing the results when all OIPs are considered as SOIPs and when few OIPs are selected as SOIPs (Gorantiwar, 1995). SOIPs appearing in the solution of the optimization model of third stage (allocation of the resources) are termed final irrigation programs.

\section{Stage 3: Allocation of the Resources}


In this stage, the land and water resources are allocated optimally to different crops grown on various soils in different locations in the command. This is done in two steps (modification of SOIPs and optimization). It is assumed that the entire command can be divided into several subcommands, each characterized by its own distribution efficiency (the efficiency of the water distribution canals supplying water from the conveyance network to individual fields) and the distance from the main feeder canal (or conveyance losses from the main feeder canal to the subcommand). Soils within the subcommand may vary and different crops can be grown in the subcommand. In first step, the SOIPs generated for different units are modified for the units in each subcommand by giving consideration to distribution and conveyance efficiencies and in second step land and water resources are optimally allocated with specified objective and constraints.

Modification of SOIPs : Less than half of the water diverted from the headworks usually reaches the crop root zone. The water lost in this process at different places is represented by different irrigation efficiencies and hence the proper consideration of these efficiencies in the allocation is very important rather than assuming by a single value (generally project efficiency). The SOIPs generated in the second stage consider the field application efficiency which may be different for different units and is a function of soil, crop, irrigation method and depth of irrigation. The other efficiencies (distribution and conveyance) which depend on characteristics of subcommand and its location in the command cannot be considered while generating SOIPs. Therefore they are modified in this third stage for variation of efficiencies with location and time. The irrigation depth of each irrigation application is adjusted for distribution and conveyance efficiencies and the total irrigation delivery (D) is obtained. The value of these efficiencies (which may vary with subcommand and irrigation) 
can be given as input to the model or decided in the model by using the values proposed by ILRI (Bos and Nugteren, 1990).

Optimization : The primary objective of this step is to allocate available land and water resources to different activities (each unit of each subcommand is a separate activity) for obtaining maximum net benefits or production or for irrigating maximum area when subjected to certain restrictions. The linear programming approach can handle this situation and is adopted to obtain the solution. The part of the optimization model which is used for the case study is described in this section. The details of the optimization model are described by Gorantiwar (1995).

\section{(1) OBJECTIVE FUNCTION}

The objective function is the maximization of the total net benefits which is the common objective for many irrigation schemes. Alternatively, if it is decided to maximize the food production instead of obtaining maximum net benefits, the objective function is the maximization of total production. However this can be adopted only when a single crop is grown in the irrigation scheme.

\section{(2) CONSTRAINTS}

The following constraints are included in the model.

(a) Area Constraints : Area to be irrigated for each soil type under each subcommand should be less than maximum available area under this soil type in the subcommand.

(b) Crop Area Related Constraints : In a multicrop situation it is possible that only one crop appears in the solution for maximizing the objective function. However the areas to be 
irrigated under different crops may need to be adjusted according to the different requirements in the irrigation scheme. These may include requirements to follow a certain crop mix, to satisfy the food requirements of the inhabitants in the command area and to restrict the area to be irrigated under different crops in a certain range. The constraints to restrict the area to be irrigated for different crops are included in the model by specifying the range of area to be irrigated for all or certain crops.

(c) Water Related Constraints :

Intraseasonal water supply : The total quantity of water applied to various activities in any intraseasonal period (irrigation period) should not be greater than the water storage available during the irrigation period under consideration.

Storage : Storage of water in the reservoir during any of the intraseasonal periods should not be less than the minimum allowable level (dead storage capacity) or more than the maximum level (reservoir capacity)

Canal capacity : Water to be released in any of the irrigation periods should not exceed the carrying capacity of the main canal. The water to be released to each subcommand during any of the irrigation periods should not exceed the capacity of the secondary/tertiary canal or outlet corresponding to the subcommand.

(d) Non-negativity constraints : The values of different activities should be greater than or equal to zero.

\section{RESULTS}


A case study is presented for the irrigation scheme in the semi-arid region of the western state of India to compare the allocation of the resources with three different allocation rules - the existing rule, full irrigation and the deficit irrigation approach- and to discuss the utility of the proposed method. The entire command area of the scheme was considered as the subcommand with a single crop (wheat), to limit the complexities in the discussion of the influence of different rules of allocation, irrigation interval and soil type on the allocation. These complexities may arise due to sensitivity of prices for different crops and variation of irrigation efficiencies of each subcommand. The culturable command area (CCA) of the project is 3072 ha and consists of five different soil types. These are described in Table 1 . The soil type 005 was not considered suitable for the cultivation of wheat. The crop period of wheat grown in the region is 120 days.

The model SWAB-CRYB of stage-1 was tested by using the field data generated at the College of Agriculture, Pune (India), $75 \mathrm{Km}$ away from the irrigation scheme (Jadhav, 1991). The linear root growth model (Fereres et al., 1981) was assumed to simulate the daily root zone depth over the crop season. The rate of moisture extraction through transpiration was considered to vary over the depth of the root zone and for that, the root zone on any day was divided into four layers, each having the same thickness and with extraction rates of 40 , 30, 20 and $10 \%$ of total actual transpiration, beginning from the top layer. The crop coefficients were estimated by using the polynomial function (equation 3) developed with lysimetric data of three years for wheat (Suryawanshi et al., 1990) at Mahatma Phule Agricultural University, Rahuri (India), $150 \mathrm{Km}$ away from the irrigation project.

$$
\mathrm{Kc}_{\mathrm{t}}=0.28+3.43\left(\frac{\mathrm{t}}{\mathrm{T}}\right)-1.44\left(\frac{\mathrm{t}}{\mathrm{T}}\right)^{2}-4.84\left(\frac{\mathrm{t}}{\mathrm{T}}\right)^{3}+2.67\left(\frac{\mathrm{t}}{\mathrm{T}}\right)^{4}
$$


where $\mathrm{Kc}=$ crop coefficient value, $\mathrm{t}=$ number of days since planting and $\mathrm{T}$ is crop period in days

The maximum grain yield that can be obtained was $4000 \mathrm{~kg} / \mathrm{ha}$. The yield response factors computed from experimental data (Jadhav, 1991) were used $(0.187,1.009,0.417$, 0.329, 0.235 and 0.017 for crown root initiation, tillering, jointing, flowering, milking and physiological maturity stages, respectively) for estimating actual grain yield by additive type of crop growth model based on evapotranspiration (Stewart and Hagan, 1973). The climatological data of the experimental site for the year 1989-90 were used. The reference crop ET was computed by a modified Penman method (Doorenbos and Pruitt, 1984 and Smith, 1991). No rainfall was received in the crop period. The minimum and maximum permissible irrigation depth values were assumed as 50 and $150 \mathrm{~mm}$ per irrigation, respectively. The initial soil moisture contents of all soil layers were assumed at field capacity as the crop season under consideration follows the rainy season. The field application efficiency, distribution efficiency and conveyance efficiency were considered as 0.75, 0.8 and 0.9 , respectively. The full supply and dead storage capacities of the reservoir were 22.31 and $5.68 \mathrm{Mm}^{3}$, respectively. The water to be kept aside for non irrigation purposes and for irrigating other areas is $8.69 \mathrm{Mm}^{3}$. The streamflow and other data (evaporation and seepage losses) were used for the year 1989-90. The carrying capacity of the main canal is $1.53 \mathrm{~m}^{3} / \mathrm{s}$.

\section{Deficit Irrigation}

The interval for computing the deficit ratio was taken as 0.1 and the deficit ratio ranged from 0 to 1 . Deficit ratio equal to 0 indicates no irrigation and equal to 1 means irrigation is applied to bring moisture in the root zone to field capacity. In fact an irrigation 
strategy having zero deficit ratio for any irrigation indicates that the irrigation application is skipped and the water delivery interval is prolonged. Thus in deficit irrigation, for a particular value of irrigation interval, the actual water delivery interval may be a multiple of the irrigation interval under consideration. However for other cases of irrigation (full irrigation and irrigation by existing rule), the irrigation interval and the water delivery interval are the same because water is applied at every turn.

The model AWAM is run for the irrigation intervals of 14, 21, 28 and 35 days. The details of ten SOIPs are presented in Table 2 for Soil - 001 and irrigation interval of 28 days. The results of the land and water allocation are presented in Table 3. It is seen from Table 3 that with deficit irrigation the allocation results (areas and production) are similar for all irrigation intervals except for 35 days. The total production is reduced when the irrigation interval is increased to 35 days. The similar results for irrigation intervals of 14, 21 and 28 days are due to the flexibility in applying the depth of irrigation for different irrigations. Irrigation strategies corresponding to the irrigation programs which appeared in the solution show that the values of deficit ratios are adjusted, or irrigations are skipped, to develop an optimum solution for these intervals. This is evident by comparing the irrigation strategies of soil-002 for intervals of 14 and 28 days. Irrigation water is allocated for the second and fourth irrigations when $\mathrm{I}=14$ days and to the first and second when $\mathrm{I}=28$ days. The slightly higher production with I=14 days is due to greater flexibility in distributing the deficits over more irrigation applications. The reduction in yield due to deficit caused by prolonging the interval up to 35 days is considerable, and therefore the total production is also less. Among the other irrigation intervals, though an interval of 14 days produces slightly more production (about 5\%), an interval of 28 days is preferable in view of possible saving in the cost of applying irrigation. However in a multicrop situation, the irrigation strategy may change due to the different sowing dates and the sensitivity of crop yield to the water availability in 
different crop growth stages. It is also seen in Table 3 that two different irrigation strategies for the same soil appeared in the solution (Soil - 001 for $\mathrm{I}=35$ days and Soil - 003 for $\mathrm{I}=21$ and 28 days). In these cases, all the area could be brought under irrigation due to deficit irrigation and after allocating all the area to the most efficient irrigation strategy, there was still some water left to be allocated. This remaining water was allocated to some area by replacing the most efficient irrigation strategy by the next most efficient irrigation strategy which gave a higher total yield than the most efficient irrigation strategy.

\section{Full Irrigation}

The allocation results for full irrigation are obtained when the irrigation is applied to fill the root zone to field capacity, as presented in Table 4. It is observed from the results that when full irrigation is given, the deficit did not occur up to an irrigation interval of 28 days for the soils appearing in the solution, and when the irrigation is prolonged further ( $I=35$ days), deficit occurred which is reflected in the reduction in yield. The higher total production for $\mathrm{I}=14,21$ and 28 days than $\mathrm{I}=35$ days indicates that the water saved due to deficit caused by prolonging the irrigation interval did not produce enough to compensate for the deficit. Irrigation intervals of 14, 21 and 28 days gave almost similar total production. Though $\mathrm{I}=21$ days gave slightly more production, $\mathrm{I}=28$ days is preferred due to the lower cost of waterings. Thus 28 days is the appropriate irrigation interval if the root zone is to be filled to field capacity at each irrigation application and higher production per unit of water consumed is needed.

The full irrigation with $I=14,21$ and 28 days represents the case of adequate irrigation as the crop was not subjected to stress except for Soil 004 for which only I=14 days represents the case of adequate irrigation (as evidenced by the yield values in Table 4). When the results of adequate irrigation are compared with the deficit irrigation for I = 14, 21 and 28 
days (Table 3), it is seen that the total production with deficit irrigation is almost twice the total production obtained with adequate irrigation. This is achieved by bringing more area under irrigation (almost two times more) with water saved due to deficit irrigation. It was possible to extend the irrigation to the entire CCA with deficit irrigation if $\mathrm{I}=21$ or 28 days. Thus in this case the practice of deficit irrigation is beneficial over the practice of adequate irrigation, when compared for obtaining crop production.

As the full irrigation with $\mathrm{I}=35$ days caused the stress, it represents the case of Approach-1 (Table 4). The full irrigation with I = 14, 21 and 28 days for Soil 001, Soil 002 and Soil 003 and full irrigation with $\mathrm{I}=14$ days for Soil 004 did not cause the stress. Therefore partial irrigations for these irrigation intervals represent Approach-2 (Table 3). As an irrigation interval of 35 days caused stress with full irrigation (Approach-1), the partial irrigation for this irrigation interval represents the case of Approach-3 (Table 3). Approach-1 and Approach-3, in which the interval is prolonged beyond the one which does not cause stress with full irrigation, give less production than Approach-2 where the irrigation interval is not prolonged as in Approach-1 and Approach-3. This indicates that deficit irrigation by prolonging the irrigation interval is not beneficial. Similarly comparing Approach-1 and Approach-3 shows that Approach-3 resulted in higher production. This indicates that deficit irrigation by applying water in depths less than required to fill the root zone to field capacity (partial irrigation) is beneficial over full irrigation.

\section{Existing Recommended Rule}

The existing recommended rule for irrigation in the scheme is to deliver $70 \mathrm{~mm}$ of water to the field or $52.5 \mathrm{~mm}$ to the root zone at each irrigation application. The results obtained with this policy are presented in Table 5. An irrigation interval of 28 days gives maximum total production. The existing recommended irrigation interval for the project is 21 
days. But if only wheat is to be irrigated, an irrigation interval of 28 days is more appropriate for this irrigation project. Irrigation intervals of 14 and 21 days do not cause any deficit and give the potential yield, but need more water due to the greater number of irrigation applications. Irrigation intervals of 14 and 21 days represent adequate irrigation. When the irrigation interval is 28 days, the recommended $52.5 \mathrm{~mm}$ water is less than the depth required to bring soil moisture to field capacity and as I = 28 days does not cause any stress with full irrigation, it is equivalent to Approach-2 except for Soil 004. An irrigation interval of 35 days represents the case of Approach-3. With application of a fixed depth of irrigation also, Approach-2 gives greater production than Approach-3. The total production amounts obtained with different approaches for a fixed depth of water application are less than those obtained with different approaches for deficit irrigation due to loss of water in deep percolation when a fixed depth of water was applied for each irrigation.

When the total production amounts obtained with irrigation intervals of 21 and 28 days are compared for the existing recommended rule and the deficit irrigation approach proposed in this paper, the deficit irrigation produces about $20-40 \%$ more total production by irrigating about 30-45\% more land. The deficit irrigation also gave $45 \%$ more total production than full irrigation by irrigating about 50\% more land. The deficit irrigation approach suggested in this paper distributes the deficit optimally over all the irrigations (by preparing irrigation programs for all possible irrigation strategies and including selected optimal irrigation programs in the optimization process) and hence it is possible to reduce the use of water per unit area. However in the full irrigation and existing rule approaches, at least the minimum possible irrigation depth is applied at every application. Therefore there is a possibility of excessive deep percolation losses when the depth of water application is low (for example during initial crop growth stages). However in the deficit irrigation depth approach, the irrigation can be skipped and hence it is possible to reduce deep percolation 
losses. Therefore with the deficit irrigation approach higher crop production is obtained by bringing more area under irrigation with the same amount of water, over existing rule of applying fixed depth of irrigation and full irrigation. This would also bring major social benefits by increasing the number of farmers receiving irrigation water.

\section{Soils}

Area and water allocation results (tables 3, 4 and 5) indicate that soil types influence the allocation of the resources. When the allocation is based on the existing recommended rule, the resources are allocated equally for a small irrigation interval, as the small irrigation interval did not cause any stress and the rule was to apply the same depth of irrigation. However as the irrigation interval is increased, the soils having lower water holding capacity (WHC) experienced more stress as they cannot store water efficiently in the root zone at the time of irrigation as compared to the soils having a higher WHC. Therefore the yields are lower for these soils for the same depth of irrigation water applied and the resources are first allocated to the soils having higher WHC. In deficit irrigation practice, the depth of irrigation can be varied at each irrigation application and for each soil. Therefore the trend is to distribute the available water optimally over all irrigation applications and soils to get maximum production and as already discussed, practicing deficit irrigation leads towards the maximization of production. The water saved through deficit irrigation of the soils having a higher WHC could bring area from other soils under irrigation. If the full irrigation is practiced, stress did not occur up to an irrigation interval of 28 days (except for soil 004), and the soils with lower WHC (among the soils which did not experience stress) got allocation first, as they needed less full depth of irrigation to give the maximum yield. However if the irrigation interval is further increased, all the soils experienced stress and area was allocated first to the soil which can keep the plant under no stress condition for a longer time (soils 
with a higher WHC). Thus the allocation of the resources varies with the soils and irrigation option, and therefore variation in soils needs to be considered in the optimization models.

\section{SUMMARY AND CONCLUSION}

The command area of a typical irrigation scheme with a rotational irrigation system in the semiarid tropics may include several soil types on which different crops can be grown. Where the availability of the water is limited compared to land, crops cannot be irrigated by applying the required depth to obtain the potential yield over the whole area. Therefore the available water needs to be allocated systematically. Under existing rules, the fixed depth of water is applied with every irrigation irrespective of the crops, their growth stages and soils on which these crops are grown in the command area of these irrigation schemes. However when water resources are scarce, it is necessary to allocate water optimally to different crops grown in the irrigation scheme taking account of different soils in the command area. Several techniques have been developed to allocate land and water resources optimally by assuming the allocation policy of one of them as known. However in the water limiting condition, as in many irrigation schemes in semi-arid regions, the optimum allocation of these resources is interdependent and so they need to be allocated together.

A three stage optimization simulation model which uses a deficit irrigation approach is described in this paper. In the first stage several irrigation programs are generated for each crop and soil type in the command. The field application efficiency is considered in this stage, based on the parameters dependent on crop and soil. The second stage selects the few most economically efficient irrigation programs. The third stage modifies the selected irrigation programs by considering distribution and conveyance efficiencies at different 
locations in the command area and allocates the resources optimally to different crops by using these irrigation programs.

The model is applied to an irrigation scheme in a semi-arid region of India by formulating a case study for a single crop (wheat) and the applicability of the model in different situations is briefly discussed. The results are obtained for the water delivery intervals of 14, 21, 28 and 35 days by a deficit irrigation approach. These are compared with full irrigation (when water is delivered to fill the root zone to field capacity) and the existing recommended rule (where water is applied in a fixed amount at every irrigation). The full irrigation with I = 14, 21 and 28 days represent adequate irrigation (no yield reductions).

It was found in the case study that when the existing recommended rule is used, an irrigation interval of 28 days is appropriate to obtain maximum production as against the standard irrigation interval of 21 days. With deficit irrigation, intervals of 14, 21 and 28 days gave similar results due to the different combinations of several depths of deficit irrigation. However the water delivery interval of 28 days is proposed in view of the possible saving on cost of applying irrigation water and operational ease. By practising the deficit irrigation approach proposed in this paper, the total production and irrigated area could be increased by $20-40 \%$ and $30-45 \%$, respectively over the existing recommended rule and by about $45 \%$ and $50 \%$, respectively over full irrigation.

The model can consider the effect of various soils on the allocation and also the effect of irrigation efficiencies which represent the major part of water consumed in the allocation process, and can be applied to irrigation schemes growing several different crops.

\section{APPENDIX. REFERENCES}


Afshar, A. and Marino, M. A. (1989). “Optimization models for wastewater reuse in irrigation ” J. Irrig. and Drain. Engrg., ASCE, 115(2), 185-202.

Akhand, N. A., Larson, D. L. and Slack, D. C. (1995). “Canal irrigation allocation planning model.” Trans. ASAE, 38(2), 545-550.

Bernardo, D. J., Whittlesey, N. K., Saxton, K. E. and Bassett, D. L. (1988). “Irrigation optimization under limited water supply.” Trans. ASAE 31, (3), 712-719.

Borg, H. and Grimes, D. W. (1986). "Depth developments of roots with time: An empirical description.” Trans. ASAE, 29(1), 194-197.

Bos, M.G. and Nugteren, J. (1990). On Irrigation Efficiencies. International Institute for Land Reclamation and Improvement, Wageningen, The Netherlands.

Bras, R. L. and Cordova, J. R. (1981). "Intraseasonal water allocation in deficit irrigation”. Water Resour. Res., 17(4), 866-874.

Doorenbos, J. and Kassam, A. H. (1986). "Yield response to water.” Food and Agric. Org. Irrig. And Drain. Paper 33, United Nations, Rome, Italy.

Doorenbos, J. and Pruitt, W. O. (1984). “Crop water requirements.” Food and Agric. Org. Irrig. And Drain. Paper 24, United Nations, Rome, Italy.

Dudley, N. J., Howell, D. T. and Musgrave, W. F. (1971). “Optimal intra-seasonal irrigation water allocation.” Water Resour. Res., 7(4), 770-788.

English, M. (1990). “Deficit irrigation I: Analytical framework.” J. Irrig. and Drain. Engrg., ASCE, 116(3), 399-412.

English, M. and Nuss, G. S. (1982). “Designing for deficit irrigation.” J. Irrig. and Drain. Engrg., ASCE, 108(IR2), 91-106.

Fereres, E., Goldfien, R. E., Pruit, W. O., Henderson, D. W. and Hagan, R. M. (1981). “The irrigation management program: A new approach to computer assisted irrigation 
scheduling”. In Proc. Irrigation Scheduling for Water and Energy Conservation in the 80's, ASAE, St. Joseph, Michigan ,USA:202-207.

Gorantiwar, S. D. (1995). “A model for planning and operation of heterogeneous irrigation schemes in semi-arid regions under rotational water supply” A Ph. D. Thesis, Loughborough University of Technology, Loughborough, Leicestershire, UK.

Hargreaves, G. H. and Samani, Z. A. (1984). “Economic considerations of deficit irrigation.” J. Irrig. and Drain. Engrg., ASCE, 110(4), 343-358.

Keller, J., Sivanappan, R. K. and.Varadan, K. M. (1992). “Design logic for deficit drip irrigation of coconut trees.” Irrigation and Drainage Systems, 6, 1-7.

Loftis, J. M. and Houghtalen, R. J. (1987). “Optimizing temporal water allocation by irrigation ditch companies.) Trans. ASAE, 30(4), 1075-1082.

Martin, D., J. van Brocklin and Wilmes, G. (1989). "Operating rules for deficit irrigation management.” Trans. ASAE, 32(4), 1207-1215.

Matanga, G. B. and Marino, M. A. (1979). “Irrigation planning 1. Cropping pattern.” Water Resour. Res., 15(3), 672-678.

Mayya, S. G. and Prasad, R. (1989). "System analysis of tank irrigation: I. Crop staggering.” J. Irrig. and Drain. Engrg., ASCE, 115(3), 384-405.

Onta, P. R., Loof, R. and Banskota, M. (1995). “Performance based irrigation planning under water shortage.” Irrigation and Drainage Systems, 9, 143-162.

Paudyal, G. N. and Gupta, A. D. (1990). “Irrigation planning by multilevel optimization.” J. Irrig. and Drain. Engrg., ASCE, 116(2), 273-291.

Paul, S., Panda, S.N. and Kumar, N. (2000). “Optimal irrigation allocation: A multilevel approach.” J. Irrig. and Drain. Engrg., ASCE, 126(3), 149-156. 
Rao, K. S. V. V. S., Reddi, T. B., Rao, M. V. J. and Reddi, G. H. S. (1986). “A rational approach for crop planning in the command areas of irrigation projects.” Institute of Engineers (India) Journal -AG 66(January):70-75

Rao, N. H., Sarma P. B. S. and Chander, S. (1990). “Optimal multicrop allocation of seasonal and intraseasonal irrigation water.” Water Resour. Res., 26(4), 551-559.

Reddy, M. J. and Clyma, W. (1983). “Choosing optimal design depth for surface irrigation system.” Agricultural Water Management, 6, 335-349.

Retta, A. and Hanks, R. J. (1980). Manual for using model PLANTGRO. Utah Agricultural Experiment Station Special Report No. 48, Logan, Utah.

Rhenals, A. E. and Bras, R. L. (1981). "The irrigation scheduling problem and evapotranspiration uncertainty.” Water Resour. Res.,17(5), 1328-1338.

Schmidt, O. and Plate, E. J. (1980). “A forecasting model for the optimal scheduling of a reservoir supplying an irrigated area in an arid environment.” In Hydrological Forecasting, IAHS Publication No. 129:491-500.

Shanan, L. (1992). "Planning and management of irrigation systems in developing countries.” Agricultural Water Management, 22, 1-234.

Shyam, R., Chauhan, H. S. and Sharma, J. S. (1994). “Optimal operation scheduling model for a canal system.” Agricultural Water Management 26, 213-225.

Smith, A. (1991). Report on the expert consultation on procedures for revision of FAO guide-lines for prediction of crop water requirements. Food and Agriculture Organization of the United Nations, Rome, Italy.

Sritharan, S. I., Clyma, W. and Richardson, E. V. (1998). “On-farm application system design and project-scale water management.” J. Irrig. and Drain. Engrg., ASCE, 114(4), 622-643. 
Sudar, R. A., Saxton, K. E. and Spomer, R. G. (1981). “A predictive model of water stress in corn and soybeans.” Trans. ASAE 24(1), 97-102.

Suryawanshi, S. N., Choudhari, D. A., Desai, P. T. and Pawar, V. S. (1990). "Crop coefficients of various crops in semi-arid tropics.” J. Indian Water Resour. Society, 10(3), 41-43.

Thandaveswara, B.S., Srinivasan, K., Babu, N. A. and Ramesh, S. K. (1992). "Modelling an overdeveloped irrigation system in South India.” Water Resour. Res., 8(1), 17-29.

Trimmer, W. L. (1990). “Applying partial irrigation in Pakistan.” J. Irrig. and Drain. Engrg., ASCE, 116(3), 342-353.

Vedula S., and Mujumdar, P. P. (1992). “Optimal reservoir operation for irrigation of multiple crops.” Water Resour. Res., 28(1), 1-9.

Walker, W. R. and Skogerboe, G. V. (1987). Surface Irrigation: Theory and Practice. Prentice Hall, Inc., Englewood Cliffs, New Jersey.

Wardlaw, R. and Barnes, J. (1999) “Optimal allocation of irrigation water supplies in real time.” J. Irrig. and Drain. Engrg., ASCE, 1125(6), 345-354.

Yaron, D. and Dinar, A. (1982). “Optimum allocation of farm irrigation water during peak seasons.” Am. J. Agr. Economics, 64 (November), 681-689. 
TABLE 1. Soils in the command area of irrigation scheme

\begin{tabular}{c|c|c|c|c|c|c}
\hline \hline \multirow{2}{*}{$\begin{array}{c}\text { Soil } \\
\text { layer }\end{array}$} & Properties & & & Soils & & \\
\cline { 3 - 7 } 1 & & 001 & 002 & 003 & 004 & 005 \\
\hline \multirow{2}{*}{2} & Thickness (mm) & 250 & 250 & 250 & 200 & 200 \\
& AWHC (mm/mm) & 0.21 & 0.19 & 0.19 & 0.2 & 0.22 \\
& Texture & SiC & C & C & L & CL \\
\multirow{2}{*}{3} & AWickness (mm) & 450 & 450 & 500 & 150 & - \\
& ThHC (mm/mm) & 0.21 & 0.21 & 0.19 & 0.185 & - \\
& Texture & SiC & SiC & C & SL & - \\
& AWHC (mm/mm) & 0.19 & 0.21 & 0.19 & - & - \\
& Texture & C & SiC & C & - & - \\
& Area (ha) & 854 & 485 & 1219 & 467 & 47 \\
\hline
\end{tabular}

AWHC: Available Water Holding Capacity

C: clay; L: loam; CL: clay loam; SL: sandy loam and SiC: silty clay 
TABLE 2. Details of irrigation programs (Irrigation interval = 28 days, Soil -001 )

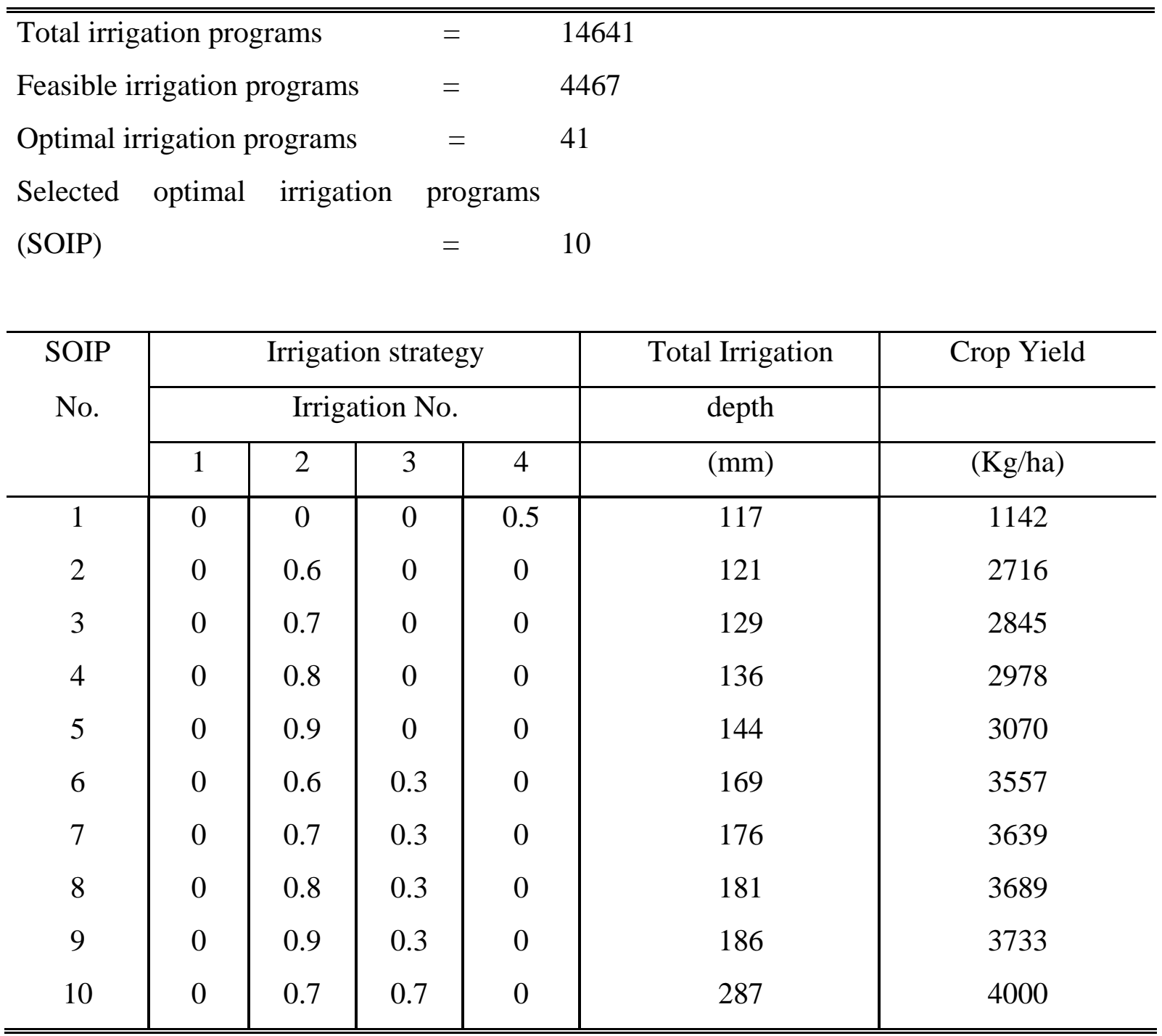


TABLE 3. Area and water allocation with deficit irrigation

\begin{tabular}{|c|c|c|c|c|c|}
\hline \multirow{2}{*}{$\begin{array}{c}\text { Irrigation } \\
\text { interval } \\
\text { (days) }\end{array}$} & \multirow[t]{2}{*}{ Soils } & $\mathrm{IDD}^{*}$ & Yield & Area & $\begin{array}{l}\text { Total crop } \\
\text { production }\end{array}$ \\
\hline & & $(\mathrm{mm})$ & (kg/ha) & (ha) & $(\mathrm{t})$ \\
\hline \multirow[t]{9}{*}{14} & 001 & 166 & 3535 & 854 & \\
\hline & \multicolumn{5}{|c|}{$(0,0.6,0.5,0,0,0,0,0)$} \\
\hline & 002 & 174 & & 485 & \\
\hline & \multicolumn{5}{|c|}{$(0,0.7,0,0.3,0,0,0,0)$} \\
\hline & 003 & 178 & 3589 & 1219 & \\
\hline & \multicolumn{5}{|c|}{$(0,0.8,0,0.3,0,0,0,0)$} \\
\hline & 004 & 316 & 3928 & 403 & \\
\hline & \multicolumn{5}{|c|}{$(1,1,1,0.9,0.8,0,0,0)$} \\
\hline & total & & & 2961 & 10721 \\
\hline \multirow[t]{11}{*}{21} & 001 & 177 & 3607 & 854 & \\
\hline & & & $(0.9,0.6,0,0,0)$ & & \\
\hline & 002 & 176 & 3521 & 485 & \\
\hline & & & $(0.9,0.6,0,0,0)$ & & \\
\hline & 003 & 173 & 3463 & 1031 & \\
\hline & & & $(0.9,0.6,0,0,0)$ & & \\
\hline & & $213^{!}$ & 3866 & 188 & \\
\hline & & & $(0.9,0.6,0.3,0,0)$ & & \\
\hline & 004 & 249 & 3196 & 467 & \\
\hline & & & $(1,0.9,0.7,0,0)$ & & \\
\hline & total & & & 3025 & 10580 \\
\hline \multirow[t]{11}{*}{28} & 001 & 181 & 3689 & 854 & \\
\hline & & & $(0.8,0.3,0,0)$ & & \\
\hline & 002 & 186 & 3679 & 485 & \\
\hline & & & $(0.9,0.3,0,0)$ & & \\
\hline & 003 & 192 & 3687 & 1101 & \\
\hline & & & $(0.8,0.4,0,0)$ & & \\
\hline & & $196^{!}$ & 3725 & 118 & \\
\hline & & & $(0.9,0.4,0,0)$ & & \\
\hline & 004 & 197 & 1710 & 467 & \\
\hline & & & $(1,0.7,0,0)$ & & \\
\hline & total & & & 3025 & 10234 \\
\hline \multirow[t]{10}{*}{35} & 001 & 189 & 3246 & 647 & \\
\hline & & & $(0.8,0.2,0)$ & & \\
\hline & & $326 !$ & 3450 & 207 & \\
\hline & & & $(1,0.7,0.2)$ & & \\
\hline & 002 & 222 & 2905 & 485 & \\
\hline & & & $(0.9,0.4,0)$ & & \\
\hline & 003 & 224 & 2902 & 1219 & \\
\hline & & & $(1,0.4,0)$ & & \\
\hline & 004 & - & - & - & \\
\hline & total & & & 2558 & 7763 \\
\hline
\end{tabular}


* IDD is seasonal gross irrigation depth, including application efficiency and excluding distribution and conveyance efficiencies, ! Second SOIP appearing in the solution.

NOTE: The figures in brackets are the values of deficit ratios for the irrigations beginning from the first irrigation 
TABLE 4. Area and water allocation for full irrigation

\begin{tabular}{|c|c|c|c|c|c|}
\hline $\begin{array}{c}\text { Irrigation } \\
\text { interval }\end{array}$ & "Soils & IDD $^{*}$ & $\overline{\text { Yield }}$ & Area & $\begin{array}{l}\text { Total crop } \\
\text { production }\end{array}$ \\
\hline (days) & & $(\mathrm{mm})$ & (kg/ha) & (ha) & $(\mathrm{t})$ \\
\hline \multirow[t]{5}{*}{14} & 001 & 422 & 4000 & - & \\
\hline & 002 & 421 & 4000 & - & \\
\hline & 003 & 413 & 4000 & 921 & \\
\hline & 004 & 407 & 4000 & 467 & \\
\hline & total & & & 1388 & 5552 \\
\hline \multirow[t]{5}{*}{21} & 001 & 402 & 4000 & - & \\
\hline & 002 & 401 & 4000 & - & \\
\hline & 003 & 393 & 4000 & 1219 & \\
\hline & 004 & 343 & 3457 & 266 & \\
\hline & total & & & 1485 & 5795 \\
\hline \multirow[t]{5}{*}{28} & 001 & 418 & 4000 & - & \\
\hline & 002 & 417 & 4000 & 175 & \\
\hline & 003 & 408 & 4000 & 1219 & \\
\hline & 004 & 300 & 2025 & - & \\
\hline & total & & & 1394 & 5795 \\
\hline \multirow[t]{5}{*}{35} & 001 & 394 & 3450 & 854 & \\
\hline & 002 & 383 & 2927 & - & \\
\hline & 003 & 374 & 2927 & 625 & \\
\hline & 004 & 240 & 972 & - & \\
\hline & total & & & 1479 & 4775 \\
\hline
\end{tabular}

* IDD is seasonal gross irrigation depth, including application efficiency and excluding distribution and conveyance efficiencies. 
TABLE 5. Area and water allocation for existing recommended rule

\begin{tabular}{|c|c|c|c|c|c|}
\hline $\begin{array}{c}\text { Irrigation } \\
\text { interval }\end{array}$ & Soils & $\begin{array}{l}\text { IDD } \\
\end{array}$ & Yield & Area & $\begin{array}{l}\text { Total crop } \\
\text { production }\end{array}$ \\
\hline (days) & & $(\mathrm{mm})$ & (kg/ha) & (ha) & $(\mathrm{t})$ \\
\hline \multirow[t]{5}{*}{14} & 001 & 560 & 4000 & 288 & \\
\hline & 002 & 560 & 4000 & 263 & \\
\hline & 003 & 560 & 4000 & 410 & \\
\hline & 004 & 560 & 4000 & 157 & \\
\hline & total & & & 1018 & 4073 \\
\hline \multirow[t]{5}{*}{21} & 001 & 350 & 4000 & 544 & \\
\hline & 002 & 350 & 4000 & 310 & \\
\hline & 003 & 350 & 4000 & 776 & \\
\hline & 004 & 350 & 3448 & - & \\
\hline & total & & & 1630 & 6518 \\
\hline \multirow[t]{5}{*}{28} & 001 & 280 & 3966 & 854 & \\
\hline & 002 & 280 & 3922 & 485 & \\
\hline & 003 & 280 & 3912 & 698 & \\
\hline & 004 & 280 & 1985 & - & \\
\hline & total & & & 2037 & 8019 \\
\hline \multirow[t]{5}{*}{35} & 001 & 210 & 3110 & 854 & \\
\hline & 002 & 210 & 2617 & 485 & \\
\hline & 003 & 210 & 2608 & 1219 & \\
\hline & 004 & 210 & 791 & - & \\
\hline & total & & & 2717 & 7230 \\
\hline
\end{tabular}

* IDD is seasonal gross irrigation depth, including application efficiency and excluding distribution and conveyance efficiencies. 
FIG.1 Schematic illustrations of deficit irrigation by Approach 1, 2 and 3 (Soil 004) (Adequate irrigation interval is 14 days) 
(a) Approach-1

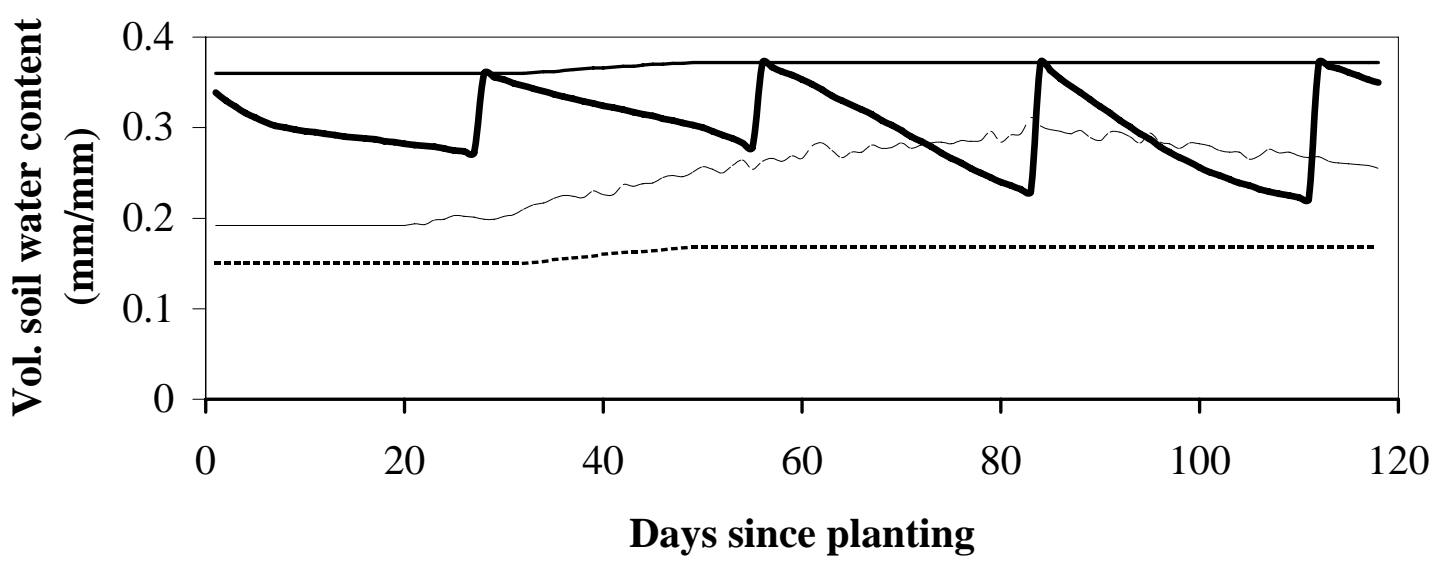

(b) Approach-2

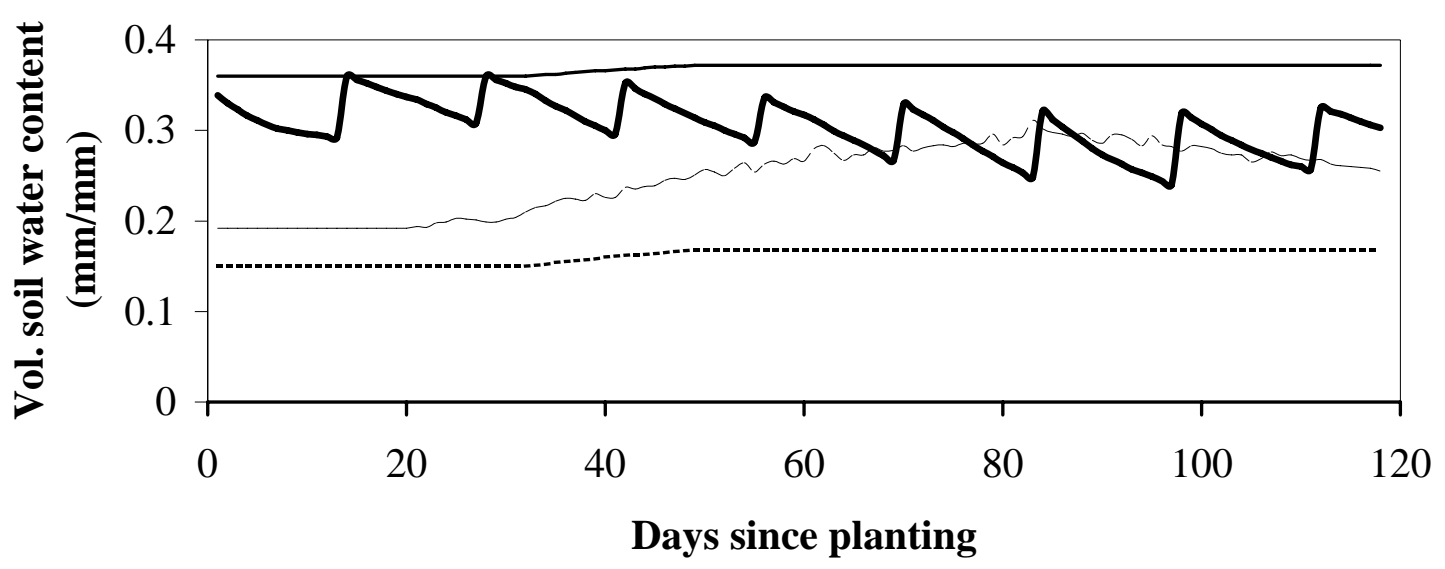

(c) Approach-3

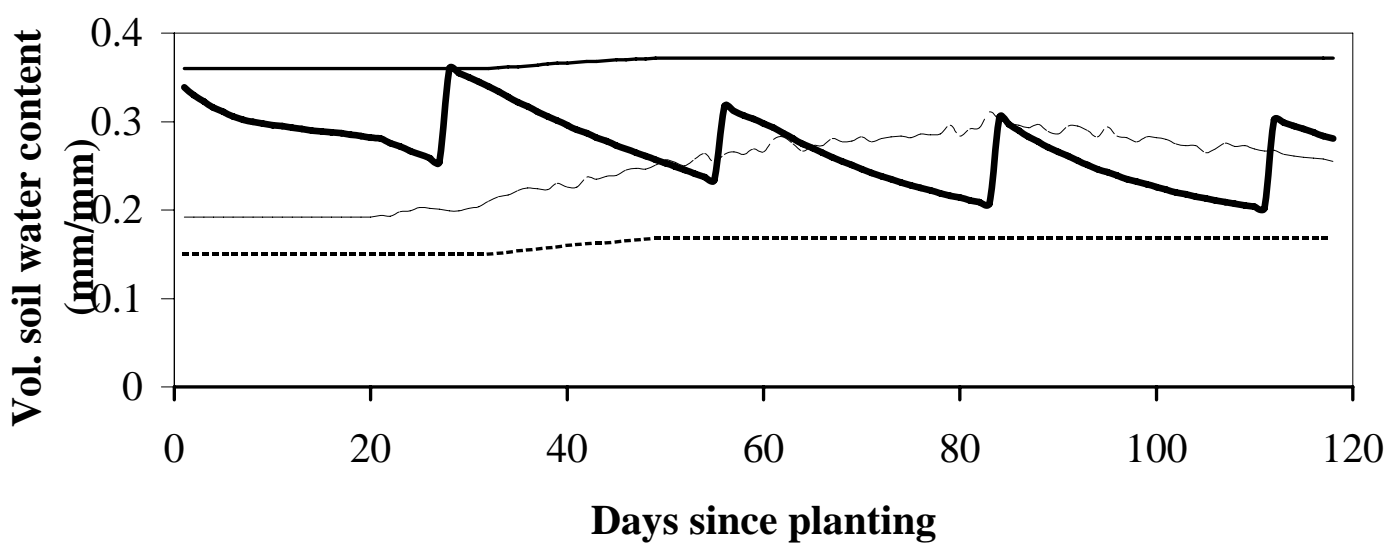

— field capacity -... - - wilting point -... readily available — soil root zone 
FIG. 2 The flow chart of area and water allocation model (AWAM) 


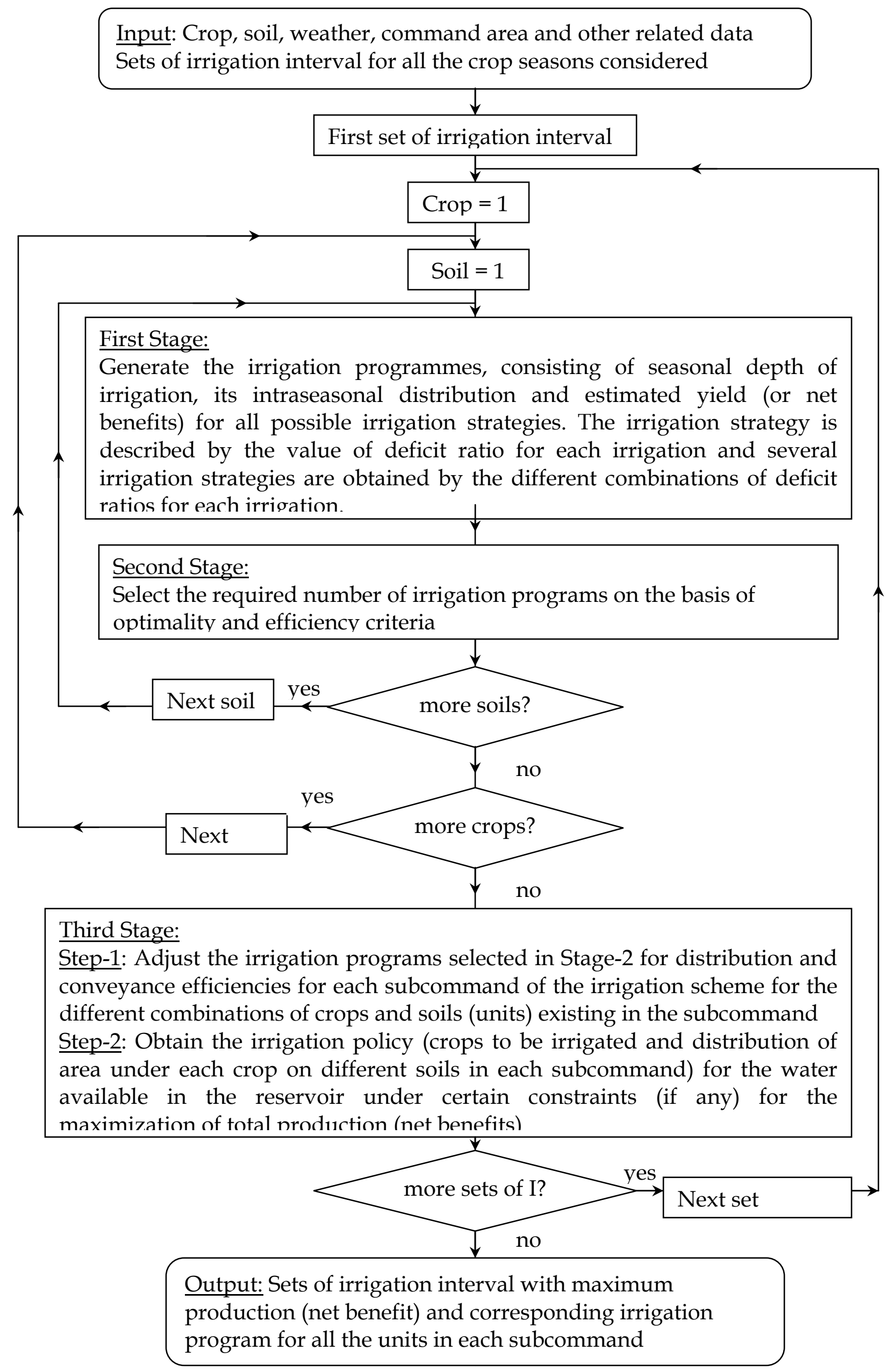

